\title{
SANITARY ANALYSIS OF ASYMPTOMATIC AND DAMAGED GRAINS OF MAIZE IN TOCANTINS, BRAZIL
}

\author{
Jaíza Francisca Ribeiro Chagas ${ }^{1}$, Rodrigo Veras da Costa $^{2}$, Gil Rodrigues dos Santos ${ }^{1}$ \\ ${ }^{1}$ Universidade Federal do Tocantins. E-mail: jafra@uft.edu.br; gilrsan@uft.edu.br \\ ${ }^{2}$ Embrapa Milho e Sorgo-Minas Gerais. E-mail: rodrigo.veras@embrapa.br
}

\section{ABSTRACT}

In the climatic conditions of the state of Tocantins, fungi have been considered limiting factors to the production of maize (Zea mays), since they favor the pathogens development in all plant parts at different stages, including during the ripening and post-harvest of maize grains. The aim of this study was to identify and quantify the fungi present in asymptomatic and damaged grains of 11 maize cultivars. For sanitary analysis, the filter paper method (Blotter test) was used. In the study, 12 maize-grainassociated genres were found: Fusarium, Aspergillus, Penicillium, Cladosporium, Trichoderma, Bipolaris, Phoma, Curvularia, Rizhopus, Colletotrichum, Papularia, and Nigrospora. There was a little variation in the diversity of genres found in damaged and asymptomatic grains, taking into account the growing seasons. The highest incidence was observed of the Fusarium genus, followed by Cladosporium, Aspergillus and Penicillium, respectively, which were associated with all the evaluated cultivars grains. The cultivars showed low percentage of damaged grains in the evaluated conditions.

Keywords: Phytopathogens, Mycoflora, Zea mays

\section{ANÁLISE SANITÁRIA DE GRÃOS ASSINTOMÁTICOS E ARDIDOS DE MILHO NO TOCANTINS, BRASIL}

\section{RESUMO}

Nas condições climáticas do estado do Tocantins, os fungos têm sido considerados fatores limitantes à produção de milho (Zea mays), pois o clima da região favorece o desenvolvimento de fitopatógenos em diferentes estágios, inclusive durante a maturação e pós-colheita dos grãos de milho. O objetivo do presente estudo foi identificar e quantificar os fungos presentes em grãos assintomáticos e ardidos de 11 cultivares de milho. Para a análise sanitária utilizou-se o método do papel de filtro (Blotter test). Foram encontrados 12 gêneros associados aos grãos do milho: Fusarium, Aspergillus, Penicillium, 
Cladosporium, Trichoderma, Bipolaris, Phoma, Curvularia, Rizhopus, Colletotrichum, Papularia e Nigrospora com pouca variação quanto à diversidade dos gêneros encontrados em grãos ardidos e assintomáticos. Maior incidência observada foi do gênero Fusarium, seguido por Cladosporium, Aspergillus e Penicillium, respectivamente, os quais estavam associados a todos os cultivares avaliados. Os cultivares apresentaram baixa porcentagem de grãos ardidos nas condições avaliadas.

Palavras-chave: Fitopatógenos, Micoflora, Zea mays

\section{INTRODUCTION}

Different pathogens attack the maize plant (Zea mays L.) in all of its vegetative stages, including on the ripening phase of the grains and on the storage, being an important cause of quantitative and qualitative losses (FREIRE et al., 2007).

The use of high-quality seeds on the maize crop is fundamental for the establishment of the crop on the fields. However, the deterioration of the seeds is a serious problem for the agriculture, being responsible for major losses worldwide and especially on the tropics, where broadly, the temperatures are elevated as well as the relative air humidity (OLIVEIRA et al., 1999).

The fungi are microorganisms with vast geographical distribution and are relevant in many economic activities, like the food production, pharmacy, enzymes, and organic acids. However, some fungi are plant pathogenic agents and food-deterioration agents, being able to cause reduction on the nutritional value of food, production of toxic secondary metabolites and diseases on humans and animals (SILVA et al., 2015).

The maize grains, in phytopathological terms, are classified as damaged when infected by fungi and when it suffers discoloration on at least a quarter of the grain surface. The coloration of these grains may vary between light-brown to purple or between light-red to dark-red, depending on the present pathogenic agent (PINTO, 2005).

Damaged grains occur mainly because of the contamination of the cobs in the phase of grain filling and the production of mycotoxins by the pathogens is constituted as one of the main problems of reduction of grain quality; including the fumonisins and aflatoxins, that cause severe health problems on animals and humans (WORDEL FILHO \& SPAGNOLLO, 2013). 
Most industries tolerate a maximum of $6 \%$ of damaged grains as quality standard on the commercial lots of maize (FREIRE et al., 2007). Due to these factors, the fungi that cause cob rottenness and consequently damaged grains must be studied more deeply.

The literature of fungi associated to maize seeds is relatively vast. However, in the state of Tocantins, Brazil, researches related to the identification and quantification of presence of fungi on grains derived from commercial cultivars are still very scarce. Therefore, the objective of this study was to identify and quantify the fungi incidence on damaged and on healthy grains of maize cultivars on this state.

\section{MATERIAL AND METHODS}

For the attainment of the grains, three experiments were carried out on field, at the experimental area of EMBRAPA, located on the municipality of Palmas, in the state of Tocantins, Brazil, with the coordinates: Latitude: 10²3'59,87' S and Longitude: 48 $21^{\prime} 42,33^{\prime \prime} \mathrm{W}$. Sowings occurred on days 03/02/2014, 25/02/2014 and 12/02/2015 with experimental establishing of blocks designed with 11 cultivars (BRS 1060, DKB 310 PRO, 30F53 YH, AS 1596 PRO, CD355, DKB 390 PRO, BRS 2020, RB9308YG, BALU 761, AG7088 PRO, and 2B587 PW) and four repetitions.

Each portion was constituted of two lines of five meters, with 0.5 meter between them, totaling a population of 55000 plants per hectare. After the harvest, 500g-samples of the maize grains were collected form each portion and later forwarded to the Phytopathology Laboratory of the Federal University of Tocantins, located on the municipality of Gurupi.

The damaged grains found in each 500g-sample were visually separated and weighted. The determination of percentage of the damaged grains was based on the weight of the sample and on the weight of the damaged grains. Subsequently, all the damaged grains and a sample with 400 asymptomatic grains from each cultivar were submitted to the sanitary test with four repetitions.

At first, the grains were submitted to a $50 \%$-alcohol asepsis for one minute, submitted to a $1 \%$ hypochlorite solution for one minute right after, and then washed in two parts of distilled water. Subsequently, the grains were submitted to the sanitary test by the method of filter paper (Blotter test), where were placed upon Germitest paper layers moist with sterile water in the interior of a transparent box (Gerbox). 
These were initially maintained for 24 hours in incubation chamber, at a temperature of $25^{\circ} \mathrm{C} \pm$ $2^{\circ}$ and next it was taken to the interior of a freezer at $-20^{\circ} \mathrm{C}$ for 24 hours, in order to inhibit the germination process of the seeds and ease the fungi identification. After that, the grains were placed again in an incubation chamber where it stayed for five days, under an alternated light scheme of 12 hours.

Finally, the process of identification and quantification of the fungi incidence was done based on their morphological characteristics, identified under a magnifying glass and an optical microscope. The identification was done using specialized literature (BARNETT \& HUNTER, 1972). When necessary, the fungi that were not identified with the magnifying glass were sent to the potato-dextrose-agar culture (PDA), for posterior microscopic identification, based on the morphological characteristics of the conidia. The fungal genres identified and quantified were expressed in percentage of incidence in each of the cultivars.

The data of the fungi incidence in each cultivar and the percentage of damaged grains were submitted to the variance analysis and the means were compared by Tukey test at 5\% of probability, using the ASSISTAT 7.7 software (SILVA, 2015). The data of percentage of the damaged grains were transformed to: $\mathrm{x}=\operatorname{arcsen} \sqrt{ } \mathrm{x} / 100$.

\section{RESULTS AND DISCUSSION}

Figures 1A and 1B show the incidence of fungi on the damaged and on the asymptomatic maize grains on the first two experiments, corresponding to the crop of 2013/2014. Among the fungi that colonized the damaged and the asymptomatic grains, these genres were more frequently found: Fusarium, Aspergillus, Penicillium, Cladosporium, Trichoderma, Bipolaris, Phoma, Curvularia, Rizhopus, and Colletotrichum, which varied differently in incidence. On the two experiments it was observed that the fungi of the genre Fusarium had high incidence, infesting more than $80 \%$ of the damaged grains studied.

On the Figure 1B, it was verified that the genre Fusarium also presented high incidence on the asymptomatic grains, with values varying between $82 \%$ and $94 \%$ on the first sowing and between $75 \%$ and $87 \%$ on the second. On the first sowing there was a higher variation on the incidence values when compared to the second one. The diversity of fungi also varied from one sowing to another, in instance Rhizopus sp. and Phoma sp., which were observed only on the first experiment and the genres Colletotrichum, Curvularia, and Nigrospora, which appeared only on the second experiment. 
A

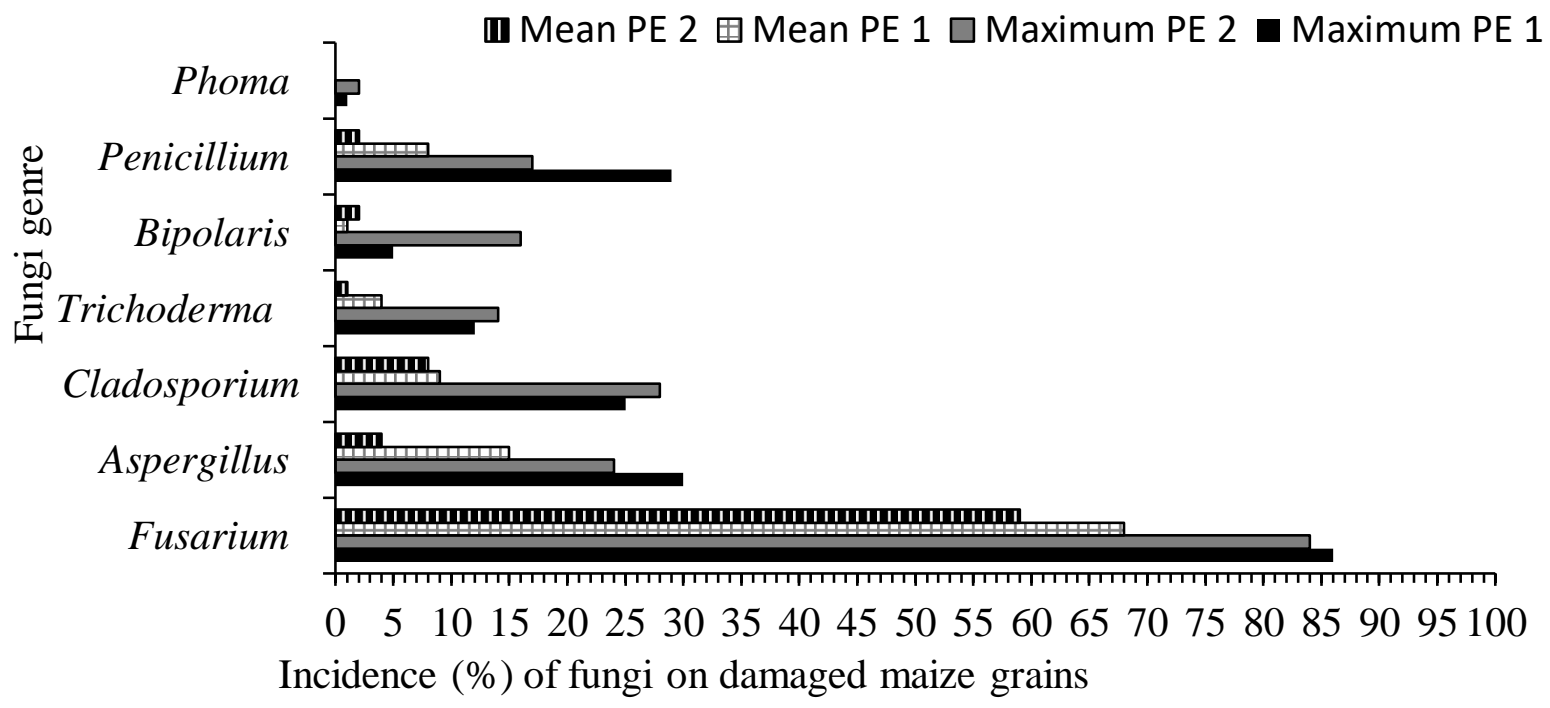

B

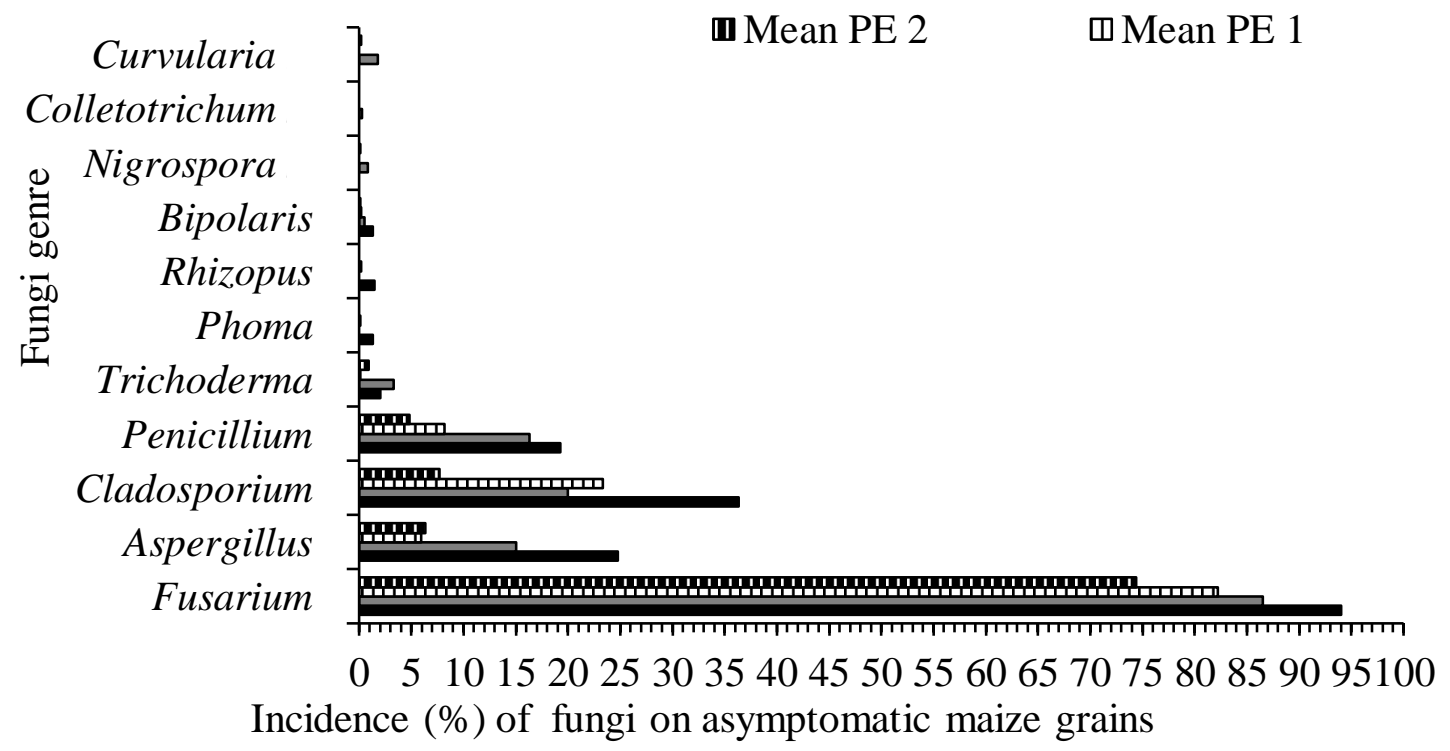

Figure 1. Mean and maximum percentage (\%) of fungi associated to damaged maize grains (A) and asymptomatic (B), period (PE1) and 2 (PE 2), Palmas, Tocantins, crop 2013/2014.

The genre Fusarium is frequently found colonizing maize grains. Many studies have already been published reporting the problems provoked by this fungus, that has as main inoculum sources the infected rests of the maize crop and also the soil (FESSEL et al., 2003; CASA et al., 2007; RAMOS et al., 2010; HENNING et al., 2011 and HUSSAIN et al., 2013). The spore dissemination occurs because of the wind and insects, and the period of higher susceptibility occurs between seven and ten days after the pollination of the stigmas. Symptomatologically, a pink (F. verticillioides) or a purple (F. graminearum) 
pigmentation may occur on the grains, and the cobs that do not double after the physiological maturity of the grains and those with bad thatch are more susceptible to this effect (PINTO, 2005).

Henning et al. (2011), in studies conducted about sanity of maize grains, found high incidence of the fungi F. moniliforme, A. flavus, and Penicillium sp. Ramos et al. (2010) also reported the presence of the fungi Penicillium sp., Fusarium sp., Aspergillus sp., Cladosporium sp., Cephalosporium sp., and Stenocarpella sp. on damaged grains and on maize seeds.

Several sowings along the year are not positives from the sanitary point of view, since this practice, together with the inadequate management, use of susceptible cultivars, and favorable climate to the development of the pathogens, increase the quantity of inoculum. Also, it should be taken into account that the majority of fungi that are causative agents of diseases remain alive in crop rests.

On the crop of 2014/2015, the presence of fungi was higher than the extracted from the two experiments from the crop of the previous year (Figure 2).

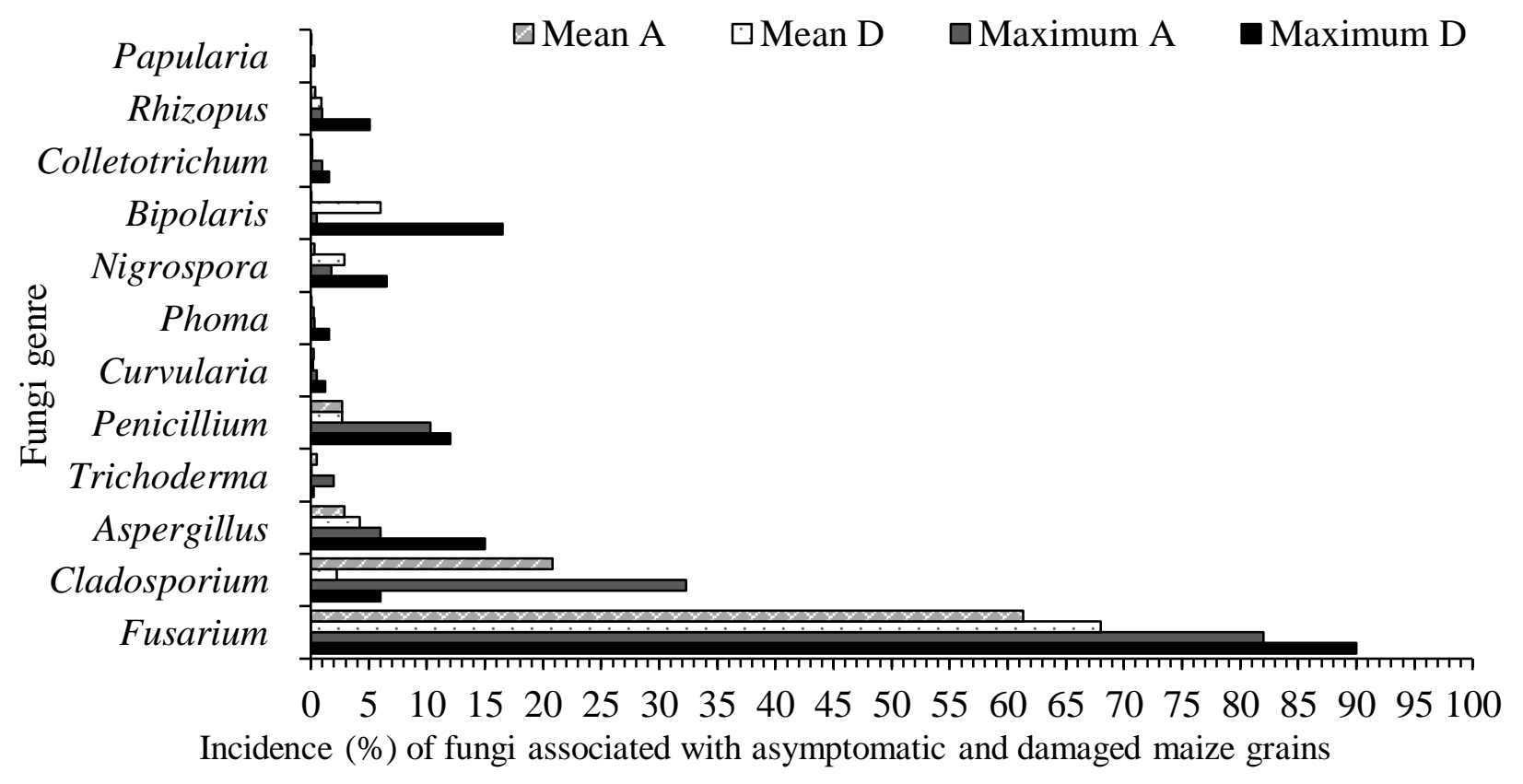

Figure 2. Mean and maximum percentage values of fungi associated with asymptomatic (A) and damaged maize grains (S), Palmas, Tocantins, crop 2014/2015.

Fusarium had mean incidence of $68 \%$ and maximum of $90 \%$ on the damaged grains. In asymptomatic grains the incidence varied from $61 \%$ to $90 \%$. Cladosporium genre was the second most incident on the asymptomatic grains, when compared to the damaged grains, with infection percentage 
varying from approximately $21 \%$ to $32 \%$. Following, the genres Aspergillus, Penicillium and Bipolaris had incidence on the damaged grain of 15\%, 12\% and 16.5\%, respectively (Figure 2).

A low incidence was registered for the genres Curvularia, Nigrospora and Rhizopus, which were already reported associated to maize grains by other authors (BENTO et al., 2012). The genres Fusarium, Cladosporium and Nigrospora found on the present study, are not commonly considered as storage fungi, except if the humidity of the grains is inadequate on the storage facilities, different from the ideal condition of humidity presented on this experiment.

However, differently from these, the genres Aspergillus, Rhizopus and Penicillium are considered storage fungi, having a very low incidence in plants on the fields and in newly-harvested grains (PEZZINI et al., 2005). Other fungi also considered of fields and that has their seeds propagated were also found on this study, for instance the Trichoderma sp., Bipolaris sp., Curvularia sp., and Colletotrichum sp.

The mean incidence values (\%) in each cultivar evaluated on the three experiments can be observed (Tables 1 and 2). Fusarium was present with high incidence on the grains of evaluated cultivars, both on the asymptomatic grains and on the damaged ones. About the efficiency of the genetic resistance of the cultivars on the incidence of fungi on damaged grains and on healthy grains of maize, the obtained results from this study demonstrated variation in the fungal microflora and on the incidence values. Independently of the evaluated crops and sanitary condition of the grains, the tested cultivars presented high susceptibility to Fusarium sp.

Considering the damaged and asymptomatic grains on the first experiment (Table 1), crop of 2013/2014, there was the presence of seven and eight fungi genre, respectively. However, it was observed that the contamination percentage varied from one cultivar to another. Each cultivar presented at least two different genre of fungi on the damaged grains and four genres on the initially considered asymptomatic. Regarding the genre that had higher incidence on the damaged grains, Fusarium infect all the cultivars, followed by Cladosporium sp., Aspergillus sp. and Trichoderma sp., which infected from six to seven cultivars. Regarding the fungi that were present on the damaged grains, all of them were found colonizing the asymptomatic grains.

The experiment 2 shows the incidence values of the presence of fungi derived from the second evaluation, crop 2013/2014 (Table 2). 
Table 1. Incidence of fungi associated to the damaged and asymptomatic grains of maize cultivars Experiment 1. Palmas, Tocantins, crop 2013/2014

\section{EXPERIMENT 1}

\begin{tabular}{llllllllllll}
\hline & \multicolumn{10}{c}{ Incidence of fungi in damaged grains (\%) } \\
\cline { 2 - 11 } Genre & 1 & 2 & 3 & 4 & 5 & 6 & 7 & 8 & 9 & 10 & 11 \\
\hline Fusarium & $90 \mathrm{aA}$ & $92 \mathrm{aA}$ & $92 \mathrm{aA}$ & $100 \mathrm{aA}$ & $94 \mathrm{aA}$ & $93 \mathrm{aA}$ & $94 \mathrm{aA}$ & $80 \mathrm{bA}$ & $90 \mathrm{aA}$ & $91 \mathrm{aA}$ & $81 \mathrm{bA}$ \\
Aspergillus & $12 \mathrm{cB}$ & $26 \mathrm{bB}$ & $0 \mathrm{dC}$ & $0 \mathrm{~dB}$ & $0,6 \mathrm{~dB}$ & $0 \mathrm{dC}$ & $0 \mathrm{~dB}$ & $1,2 \mathrm{~dB}$ & $0 \mathrm{~dB}$ & $52 \mathrm{aB}$ & $3 \mathrm{~dB}$ \\
Penicilium & $0 \mathrm{bC}$ & $0,5 \mathrm{bC}$ & $20 \mathrm{aB}$ & $0 \mathrm{bB}$ & $0 \mathrm{bB}$ & $5,5 \mathrm{bB}$ & $0 \mathrm{bB}$ & $0 \mathrm{bB}$ & $0 \mathrm{bB}$ & $0 \mathrm{bC}$ & $0 \mathrm{bB}$ \\
Cladosporium & $13 \mathrm{aB}$ & $1,5 \mathrm{bC}$ & $0 \mathrm{bC}$ & $0 \mathrm{bB}$ & $6 \mathrm{bB}$ & $11 \mathrm{bB}$ & $0 \mathrm{bB}$ & $1 \mathrm{bB}$ & $2 \mathrm{bB}$ & $0 \mathrm{bC}$ & $1 \mathrm{bB}$ \\
Trichoderma & $14 \mathrm{aB}$ & $1 \mathrm{bC}$ & $0 \mathrm{bC}$ & $0 \mathrm{bB}$ & $0 \mathrm{bB}$ & $1 \mathrm{bC}$ & $4,5 \mathrm{bB}$ & $0 \mathrm{bB}$ & $0 \mathrm{bB}$ & $1 \mathrm{bC}$ & $6 \mathrm{bB}$ \\
Phoma & $0 \mathrm{aC}$ & $0 \mathrm{aC}$ & $0 \mathrm{aC}$ & $0 \mathrm{aB}$ & $0 \mathrm{aB}$ & $0 \mathrm{aC}$ & $0 \mathrm{aB}$ & $0 \mathrm{aB}$ & $0 \mathrm{aB}$ & $0 \mathrm{aC}$ & $0 \mathrm{aB}$ \\
Bipolaris & $0 \mathrm{aC}$ & $0 \mathrm{aC}$ & $0 \mathrm{aC}$ & $0 \mathrm{aB}$ & $0 \mathrm{aB}$ & $0 \mathrm{aC}$ & $0 \mathrm{aB}$ & $0 \mathrm{aB}$ & $0 \mathrm{aB}$ & $0 \mathrm{aC}$ & $0 \mathrm{aB}$ \\
\hline
\end{tabular}

Incidence of fungi in asymptomatic grains of maize (\%)

Cultivars ${ }^{1}$

\begin{tabular}{|c|c|c|c|c|c|c|c|c|c|c|c|}
\hline Genre & 1 & 2 & 3 & 4 & 5 & 6 & 7 & 8 & 9 & 10 & 11 \\
\hline Fusarium & $79 \mathrm{dA}$ & 86abcdA & 93abA & 87abcdA & 94abA & 92abcA & $85 \mathrm{bcdA}$ & 94abA & $93 \mathrm{abA}$ & $82 \mathrm{cdA}$ & $96 \mathrm{aA}$ \\
\hline Aspergillus & $2,3 \mathrm{cdC}$ & $2 \mathrm{cdC}$ & $3 b c d B$ & $2 \mathrm{cdC}$ & $10 \mathrm{abcBC}$ & $0 \mathrm{dD}$ & $13 \mathrm{abC}$ & $1 \mathrm{cdC}$ & $18 \mathrm{aC}$ & $6 \mathrm{bcC}$ & $8 \mathrm{abcdC}$ \\
\hline Penicilium & $5,5 \mathrm{bcC}$ & $13 \mathrm{abB}$ & $4,5 \mathrm{bcB}$ & $3,5 \mathrm{bcC}$ & $2 \mathrm{cCD}$ & $17 \mathrm{aC}$ & $22 \mathrm{aC}$ & $0 \mathrm{cC}$ & $12 \mathrm{abC}$ & $3 b c C$ & $6 \mathrm{bcC}$ \\
\hline Cladosporim & $47 \mathrm{aB}$ & $6 \mathrm{eBC}$ & $9 \mathrm{deB}$ & $41 \mathrm{aB}$ & $17 \mathrm{cdB}$ & $43 \mathrm{aB}$ & $23 \mathrm{bcB}$ & $19 \mathrm{cdB}$ & $24 \mathrm{bcB}$ & $41 \mathrm{aB}$ & $30 \mathrm{bB}$ \\
\hline Trichoderma & $4 \mathrm{aC}$ & $0,3 \mathrm{aC}$ & $0,6 \mathrm{aB}$ & $1 \mathrm{aC}$ & $3 \mathrm{aCD}$ & $0,3 \mathrm{aD}$ & $0 \mathrm{aD}$ & $0,3 \mathrm{aC}$ & $0,6 \mathrm{aD}$ & $0,6 \mathrm{aC}$ & $0 \mathrm{aC}$ \\
\hline Bipolaris & $0 \mathrm{aC}$ & $0 \mathrm{aC}$ & $0 \mathrm{aB}$ & $2 \mathrm{aC}$ & $0 \mathrm{aD}$ & $0,3 \mathrm{aD}$ & $0 \mathrm{aD}$ & $0 \mathrm{aC}$ & $0 \mathrm{aD}$ & $0 \mathrm{aC}$ & $0 \mathrm{aC}$ \\
\hline Phoma & $0 \mathrm{aC}$ & $0 \mathrm{aC}$ & $0 \mathrm{aB}$ & $0 \mathrm{aC}$ & $0 \mathrm{aD}$ & $0 \mathrm{aD}$ & $0 \mathrm{aD}$ & $0 \mathrm{aC}$ & $0 \mathrm{aD}$ & $2 \mathrm{aC}$ & $0 \mathrm{aC}$ \\
\hline Rhizopus & $0 \mathrm{aC}$ & $0 \mathrm{aC}$ & $0 \mathrm{aB}$ & $0 \mathrm{aC}$ & $0 \mathrm{aD}$ & $0 \mathrm{aD}$ & $0 \mathrm{aD}$ & $0 \mathrm{aC}$ & $2 \mathrm{aD}$ & $3 \mathrm{aC}$ & $0 \mathrm{aC}$ \\
\hline
\end{tabular}

${ }^{1}$ Cultivars: 1(AS1596PRO), 2 (DKB310PRO), 3(CD35), 4 (AG7088PRO), 5 (2B587PW), 6 (DKB390PRO), 7 (BRS1060), 8 (RB9308YG), 9 (BALU761) 10 (30F53YH) e 11 (BRS2020). Means followed by the same letter, lower case comparing in the row and upper case in the column does not differ statistically by the Scott-Knott test at 5\%

The quantity of genres present on the damaged and on the asymptomatic grains were the same observed on the first experiment, with few differences on the diversity of fungi on both experiments. On the second experiment, there was found again the same tendency observed previously, where higher quantity of genres was found on the healthy grains. 
Table 2: Incidence of fungi associated to the damaged and asymptomatic grains of maize cultivars Experiment 2. Palmas, Tocantins, crop 2013/2014

\section{EXPERIMENT 2}

\section{Incidence of fungi in damaged grains $(\%)$}

\begin{tabular}{llllllllllll}
\hline \multicolumn{10}{c}{ Incidence of fungi in damaged grains (\%) } \\
\hline Genre & 1 & 2 & 3 & 4 & 5 & 6 & 7 & 8 & 9 & 10 & 11 \\
\hline Fusarium & $90 \mathrm{aA}$ & $92 \mathrm{aA}$ & $92 \mathrm{aA}$ & $100 \mathrm{aA}$ & $94 \mathrm{aA}$ & $93 \mathrm{aA}$ & $93 \mathrm{aA}$ & $79 \mathrm{bA}$ & $90 \mathrm{aA}$ & $91 \mathrm{aA}$ & $81 \mathrm{bA}$ \\
Aspergillus & $12 \mathrm{cB}$ & $26 \mathrm{bB}$ & $0 \mathrm{dC}$ & $0 \mathrm{~dB}$ & $0,6 \mathrm{~dB}$ & $0 \mathrm{dC}$ & $0 \mathrm{~dB}$ & $1,2 \mathrm{~dB}$ & $0 \mathrm{~dB}$ & $52 \mathrm{aB}$ & $3 \mathrm{~dB}$ \\
Penicillium & $0 \mathrm{bC}$ & $0,6 \mathrm{bC}$ & $20 \mathrm{aB}$ & $0 \mathrm{bB}$ & $0 \mathrm{bB}$ & $5,5 \mathrm{bB}$ & $0 \mathrm{bB}$ & $0 \mathrm{bB}$ & $0 \mathrm{bB}$ & $0 \mathrm{bC}$ & $0 \mathrm{bB}$ \\
Cladosporim & $13 \mathrm{aB}$ & $1,5 \mathrm{bC}$ & $0 \mathrm{bC}$ & $0 \mathrm{bB}$ & $6 \mathrm{bB}$ & $11 \mathrm{aB}$ & $0 \mathrm{bB}$ & $1 \mathrm{bB}$ & $1,7 \mathrm{bB}$ & $0 \mathrm{bC}$ & $1,8 \mathrm{bB}$ \\
Trichoderma & $13 \mathrm{aB}$ & $1 \mathrm{bC}$ & $0 \mathrm{bC}$ & $0 \mathrm{bB}$ & $0 \mathrm{bB}$ & $1 \mathrm{bC}$ & $4,5 \mathrm{bB}$ & $0 \mathrm{bB}$ & $0 \mathrm{bB}$ & $1 \mathrm{bC}$ & $6 \mathrm{bB}$ \\
Bipolaris & $0 \mathrm{aC}$ & $0 \mathrm{aC}$ & $0 \mathrm{aC}$ & $0 \mathrm{aB}$ & $0 \mathrm{aB}$ & $0 \mathrm{aC}$ & $0 \mathrm{aB}$ & $0 \mathrm{aB}$ & $0 \mathrm{aB}$ & $0 \mathrm{aC}$ & $0 \mathrm{aB}$ \\
Curvularia & $0 \mathrm{aC}$ & $0 \mathrm{aC}$ & $0 \mathrm{aC}$ & $0 \mathrm{aB}$ & $0 \mathrm{aB}$ & $0 \mathrm{aC}$ & $0 \mathrm{aB}$ & $0 \mathrm{aB}$ & $0 \mathrm{aB}$ & $0 \mathrm{aC}$ & $0 \mathrm{aB}$ \\
\hline
\end{tabular}

Incidence of fungi in asymptomatic grains of maize (\%)

\begin{tabular}{lllllllllllll}
\hline Genre & 1 & 2 & 3 & 4 & 5 & 6 & 7 & 8 & 9 & 10 & 11 \\
\hline Fusarium & $94 \mathrm{abA}$ & $87 \mathrm{bcA}$ & $82 \mathrm{cdA}$ & $86 \mathrm{bcA}$ & $98 \mathrm{aA}$ & $76 \mathrm{deA}$ & $69 \mathrm{efA}$ & $73 \mathrm{eA}$ & $59 \mathrm{gA}$ & $63 \mathrm{fgA}$ & $93 \mathrm{abA}$ \\
Aspergillus & $9 \mathrm{aC}$ & $6 \mathrm{aBC}$ & $1,3 \mathrm{aBC}$ & $3 \mathrm{aB}$ & $3 \mathrm{aC}$ & $0,3 \mathrm{aB}$ & $3 \mathrm{aB}$ & $1 \mathrm{aC}$ & $0,3 \mathrm{aB}$ & $4,3 \mathrm{aB}$ & $1 \mathrm{aB}$ \\
Penicilium & $0,6 \mathrm{bD}$ & $10 \mathrm{aB}$ & $4 \mathrm{abBC}$ & $0 \mathrm{bB}$ & $0,6 \mathrm{bC}$ & $0,3 \mathrm{bB}$ & $2,3 \mathrm{abB}$ & $0,3 \mathrm{bC}$ & $1,6 \mathrm{abB}$ & $1,3 \mathrm{abB}$ & $4 \mathrm{abB}$ \\
Cladosporim & $35 \mathrm{aB}$ & $7 \mathrm{cB}$ & $8 \mathrm{cBC}$ & $3 \mathrm{cB}$ & $18 \mathrm{bB}$ & $8 \mathrm{cB}$ & $2 \mathrm{cB}$ & $19 \mathrm{bB}$ & $5 \mathrm{cB}$ & $2 \mathrm{cB}$ & $4 \mathrm{cB}$ \\
Trichoderma & $0 \mathrm{aD}$ & $0 \mathrm{aC}$ & $1 \mathrm{aBC}$ & $0,5 \mathrm{aB}$ & $1 \mathrm{aC}$ & $1 \mathrm{aB}$ & $0 \mathrm{aB}$ & $0 \mathrm{aC}$ & $0 \mathrm{aB}$ & $0 \mathrm{aB}$ & $1 \mathrm{aB}$ \\
Bipolaris & $0,5 \mathrm{aD}$ & $0 \mathrm{aC}$ & $0,5 \mathrm{aBC}$ & $0 \mathrm{aB}$ & $0 \mathrm{aC}$ & $0 \mathrm{aB}$ & $0 \mathrm{aB}$ & $0 \mathrm{aC}$ & $1 \mathrm{aB}$ & $0 \mathrm{aB}$ & $0 \mathrm{aB}$ \\
Curvularia & $0 \mathrm{aD}$ & $0 \mathrm{aC}$ & $0 \mathrm{aC}$ & $3 \mathrm{aB}$ & $0 \mathrm{aC}$ & $0 \mathrm{aB}$ & $0 \mathrm{aB}$ & $0 \mathrm{aC}$ & $0 \mathrm{aB}$ & $0 \mathrm{aB}$ & $0 \mathrm{aB}$ \\
Nigrospora & $0 \mathrm{aD}$ & $0 \mathrm{aC}$ & $0 \mathrm{aC}$ & $0 \mathrm{aB}$ & $0 \mathrm{aC}$ & $0 \mathrm{aB}$ & $0 \mathrm{aB}$ & $0 \mathrm{aC}$ & $0 \mathrm{aB}$ & $0 \mathrm{aB}$ & $1,5 \mathrm{aB}$ \\
\hline
\end{tabular}

${ }^{1}$ Cultivars: 1(AS1596PRO), 2 (DKB310PRO), 3(CD35), 4 (AG7088PRO), 5 (2B587PW), 6 (DKB390PRO), 7 (BRS1060), 8 (RB9308YG), 9 (BALU761) 10 (30F53YH) e 11 (BRS2020). Means followed by the same letter, lower case comparing in the row and upper case in the column does not differ statistically by the Scott-Knott test at $5 \%$

Regarding the incidence of grains on the crop 2014/2015 (Table 3), it was observed the same tendency on the experiments of the previous crop, with more incidence of the genres Fusarium, Aspergillus, Penicillium, and Cladosporium again. 


\section{SANITARY ANALYSIS OF ASYMPTOMATIC AND DAMAGED GRAINS OF MAIZE IN TOCANTINS, BRAZIL}

Table 3. Incidence of fungi associated to the damaged and asymptomatic grains of maize cultivars Experiment 3. Palmas, Tocantins, crop 2014/2015.

Incidence of fungi in damaged grains $(\%)$

\section{Cultivars}

\begin{tabular}{|c|c|c|c|c|c|c|c|c|c|c|c|}
\hline Genre & $\overline{1}$ & 2 & 3 & 4 & 5 & 6 & 7 & 8 & 9 & 10 & 11 \\
\hline Fusarium & 97abA & $93 \mathrm{bA}$ & 97abA & 96abA & $93 \mathrm{bA}$ & 96abA & 96abA & $100 \mathrm{aA}$ & $93 \mathrm{bA}$ & 97abA & $73 \mathrm{cA}$ \\
\hline Aspergillus & $7 \mathrm{bB}$ & $4 \mathrm{bBC}$ & $0 \mathrm{cB}$ & $0 \mathrm{cC}$ & $7 \mathrm{bBC}$ & $0 \mathrm{cB}$ & $20 \mathrm{aB}$ & $5 \mathrm{bB}$ & $7 \mathrm{bB}$ & $0 \mathrm{cC}$ & $0,6 \mathrm{bcB}$ \\
\hline Penicillium & $0,6 \mathrm{bC}$ & $13 \mathrm{bBC}$ & ObB & $2 \mathrm{bC}$ & $9 \mathrm{aB}$ & $0 \mathrm{bB}$ & $1,3 \mathrm{bC}$ & $1,5 \mathrm{bB}$ & $0 \mathrm{bC}$ & $0,3 \mathrm{bC}$ & $2 \mathrm{bB}$ \\
\hline Cladosporim & $4 a b B C$ & $7 \mathrm{aB}$ & $0 \mathrm{bB}$ & $3 a b B C$ & 6abBCD & $1,5 \mathrm{abB}$ & $0 \mathrm{bC}$ & $2 \mathrm{abB}$ & $5,5 \mathrm{abC}$ & $7 \mathrm{aB}$ & ObB \\
\hline Bipolaris & $0 \mathrm{aC}$ & $1 \mathrm{aBC}$ & $0,5 \mathrm{aB}$ & $0 \mathrm{aC}$ & $0 \mathrm{aD}$ & $2 \mathrm{aB}$ & $0 \mathrm{aC}$ & $1,5 \mathrm{aB}$ & $0 \mathrm{aC}$ & $5,6 \mathrm{aBC}$ & $5 \mathrm{aB}$ \\
\hline Curvularia & $0 \mathrm{aC}$ & $0 \mathrm{aC}$ & $0 \mathrm{aB}$ & $0 \mathrm{aC}$ & $2,5 \mathrm{aCD}$ & $1 \mathrm{aB}$ & $0 \mathrm{aC}$ & $0 \mathrm{aB}$ & $0 \mathrm{aC}$ & $0 \mathrm{aC}$ & $0 \mathrm{aB}$ \\
\hline Phoma & $0 \mathrm{aC}$ & $2 \mathrm{aBC}$ & $0,5 \mathrm{aB}$ & $3 \mathrm{aBC}$ & $0 \mathrm{aD}$ & $0 \mathrm{aB}$ & $0 \mathrm{aC}$ & $0 \mathrm{aB}$ & $0,5 \mathrm{aC}$ & $0 \mathrm{aC}$ & $0 \mathrm{aB}$ \\
\hline Nigrospora & $0 \mathrm{aC}$ & $1 \mathrm{aBC}$ & $2,6 \mathrm{aB}$ & $1,3 \mathrm{aC}$ & $0 \mathrm{aD}$ & $0 \mathrm{aB}$ & $0 \mathrm{aC}$ & $0 \mathrm{aB}$ & $0,5 \mathrm{aC}$ & $0 \mathrm{aC}$ & $0 \mathrm{aB}$ \\
\hline
\end{tabular}

Incidence of fungi in asymptomatic grains of maize $(\%)$

\begin{tabular}{llllllllllll}
\hline & \multicolumn{10}{c}{ Cultivars $^{1}$} \\
\cline { 2 - 6 } Genre & 1 & 2 & 3 & 4 & 5 & 6 & 7 & 8 & 9 & 10 & 11 \\
\hline Fusarium & $84 \mathrm{abA}$ & $91 \mathrm{aA}$ & $63 \mathrm{cA}$ & $90 \mathrm{aA}$ & $86 \mathrm{abA}$ & $80 \mathrm{bA}$ & $78 \mathrm{bA}$ & $63 \mathrm{cA}$ & $86 \mathrm{abA}$ & $85 \mathrm{abA}$ & $92 \mathrm{aA}$ \\
Aspergillus & $1 \mathrm{aC}$ & $4 \mathrm{aC}$ & $2 \mathrm{aB}$ & $5 \mathrm{aBC}$ & $4 \mathrm{aC}$ & $1 \mathrm{aC}$ & $3 \mathrm{aC}$ & $0 \mathrm{aC}$ & $4 \mathrm{aC}$ & $4 \mathrm{aC}$ & $1 \mathrm{aC}$ \\
Penicilium & $1 \mathrm{aC}$ & $6 \mathrm{aC}$ & $4 \mathrm{aB}$ & $2 \mathrm{aC}$ & $2 \mathrm{aC}$ & $7 \mathrm{aC}$ & $2 \mathrm{aC}$ & $0 \mathrm{aC}$ & $2 \mathrm{aC}$ & $0 \mathrm{aC}$ & $4 \mathrm{aC}$ \\
Cladosporim & $24 \mathrm{abcB}$ & $26 \mathrm{abB}$ & $8 \mathrm{~dB}$ & $14 \mathrm{~dB}$ & $23 \mathrm{abcB}$ & $17 \mathrm{bcdB}$ & $16 \mathrm{cdB}$ & $28 \mathrm{aB}$ & $12 \mathrm{~dB}$ & $10 \mathrm{~dB}$ & $16 \mathrm{cdB}$ \\
Trichoderma & $1 \mathrm{aC}$ & $2 \mathrm{aC}$ & $0 \mathrm{aB}$ & $0 \mathrm{aC}$ & $0,5 \mathrm{aC}$ & $0,5 \mathrm{aC}$ & $0,5 \mathrm{aC}$ & $0,5 \mathrm{aC}$ & $0 \mathrm{aC}$ & $0 \mathrm{aC}$ & $4 \mathrm{aC}$ \\
Bipolaris & $0,5 \mathrm{aC}$ & $0 \mathrm{aC}$ & $0 \mathrm{aB}$ & $0 \mathrm{aC}$ & $0,5 \mathrm{aC}$ & $0 \mathrm{aC}$ & $0,5 \mathrm{aC}$ & $0 \mathrm{aC}$ & $0 \mathrm{aC}$ & $0 \mathrm{aC}$ & $0 \mathrm{aC}$ \\
Curvularia & $1 \mathrm{aC}$ & $1 \mathrm{aC}$ & $1 \mathrm{aB}$ & $0 \mathrm{aC}$ & $0,5 \mathrm{aC}$ & $0,5 \mathrm{aC}$ & $0 \mathrm{aC}$ & $0 \mathrm{aC}$ & $0 \mathrm{aC}$ & $0 \mathrm{aC}$ & $0,3 \mathrm{aC}$ \\
Nigrospora & $0 \mathrm{aC}$ & $0 \mathrm{aC}$ & $0 \mathrm{aB}$ & $0 \mathrm{aC}$ & $0 \mathrm{aC}$ & $0 \mathrm{aC}$ & $1,5 \mathrm{aC}$ & $0 \mathrm{aC}$ & $0 \mathrm{aC}$ & $0 \mathrm{aC}$ & $0 \mathrm{aC}$ \\
Colletotrichum & $0 \mathrm{aC}$ & $0,5 \mathrm{aC}$ & $0 \mathrm{aB}$ & $0 \mathrm{aC}$ & $0 \mathrm{aC}$ & $0 \mathrm{aC}$ & $0,5 \mathrm{aC}$ & $0 \mathrm{aC}$ & $0 \mathrm{aC}$ & $2 \mathrm{aBC}$ & $0 \mathrm{aC}$ \\
Phoma & $0 \mathrm{aC}$ & $0,5 \mathrm{aC}$ & $0 \mathrm{aB}$ & $0 \mathrm{aC}$ & $0 \mathrm{aC}$ & $0 \mathrm{aC}$ & $0 \mathrm{aC}$ & $0 \mathrm{aC}$ & $0 \mathrm{aC}$ & $0,5 \mathrm{aC}$ & $0 \mathrm{aC}$ \\
Papularia & $0 \mathrm{aC}$ & $0 \mathrm{aC}$ & $0 \mathrm{aB}$ & $0 \mathrm{aC}$ & $0 \mathrm{aC}$ & $0,5 \mathrm{aC}$ & $0 \mathrm{aC}$ & $1 \mathrm{aC}$ & $0 \mathrm{aC}$ & $0 \mathrm{aC}$ & $0 \mathrm{aC}$ \\
Rhizopus & $1 \mathrm{aC}$ & $0,5 \mathrm{aC}$ & $0 \mathrm{aB}$ & $0 \mathrm{aC}$ & $0 \mathrm{aC}$ & $0 \mathrm{aC}$ & $0 \mathrm{aC}$ & $0 \mathrm{aC}$ & $0 \mathrm{aC}$ & $1,5 \mathrm{aBC}$ & $0 \mathrm{aC}$ \\
\hline
\end{tabular}

${ }^{1}$ Cultivars: 1(AS1596PRO), 2 (DKB310PRO), 3(CD35), 4 (AG7088PRO), 5 (2B587PW), 6 (DKB390PRO), 7 (BRS1060), 8 (RB9308YG), 9 (BALU761) 10 (30F53YH) e 11 (BRS2020). Means followed by the same letter, lower case comparing in the row and upper case in the column does not differ statistically by the Scott-Knott test at $5 \%$.

Other fungi were identified on the damaged and on the asymptomatic grains in this period, even in lower incidence levels. Papularia genre was found only in the last experiment on the asymptomatic grains of cultivars RB9308YG and DKB390PRO with very low incidence (Table 3). Papularia sp. and 42 
Nigrospora sp. are also considered intermediate fungi, because they develop on mature or immature grains (FIGUEIRA et al., 2003).

The present study demonstrated that even apparently healthy (or asymptomatic) grains, when placed under humidity and favorable temperature, allow the development of previously present fungi. This fact is preoccupying when the grains are destined to feeding, resulting in food with possible toxins, as well as the seeds, because the germination can transmit the phytopathogens. Like the genre obtained in this study, for instance, the Bipolaris, Colletotrichum, Fusarium, Aspergillus, Penicillium, etc. are associated to the rottenness of maize seeds and death of seedlings in pre and post-emergency (HENNING et al., 2011).

The percentage values of damaged grains of each cultivar are presented in the table 4 . It can be observed that in the experiment 1, crop 2013/2014 (Table 4), the cultivar BALU 761 presented the highest percentage of damaged grains, statistically differing from the cultivar BRS1060. Statistically, nine cultivars did not differ from the cultivars BALU 761 and BRS 1060. None of the cultivars passed the maximum limit of tolerance of $6 \%$ established as maximum value for the presence of damaged grains in lots of maize grains in Brazil.

In the second experiment, also, there was no percentage higher than the allowed, but again the cultivar BALU 761 presented highest percentage, differing from the cultivar DKB 390 PRO. Four cultivars did not statistically differ from the cultivar BALU 761. It was observed that in the crop of 2014/2015 (experiment 3), the hybrid 30F53 YH had higher percentage of damaged grains.

The observed values above the allowed of $6 \%$ may have occurred due to the presence of plague insects on the samples. These insects, when present, favor the higher contamination by the fungi, due to the damages they cause to the grains when they tear the cell wall to feed themselves, favoring the faster and more efficient penetration of the fungi.

The control and evaluation of the maximum tolerance limits to infected maize grains have high importance for food health of animals and humans, because as said by Hermanns et. al. (2006), the maize is one of the most susceptible grains to contamination by fungi considered toxigenic and to the accumulation of toxins that they produce. These mycotoxins are results of the secondary metabolism of some genres found on this present study, like Aspergillus sp., Penicillium sp. and Fusarium sp., which can inappropriate the grains for consumption, resulting in considerable quality and economic losses, fostering risks to health. 
Table 4 - Percentage of damaged grains in the maize cultivars. Palmas, Tocantins, crop 2013/2014 and $2014 / 2015$.

\begin{tabular}{llll}
\hline Cultivars & Experiment $1^{(1)}$ & Experiment $2^{(1)}$ & ${\text { Experiment } 3^{(1)}}^{(1)}$ \\
\hline AS1596 PRO & $0,59 \mathrm{ab}$ & $0,44 \mathrm{abc}$ & $5,4 \mathrm{ab}$ \\
DKB310 PRO & $0,79 \mathrm{ab}$ & $0,28 \mathrm{bc}$ & $3,8 \mathrm{ab}$ \\
CD355 & $0,68 \mathrm{ab}$ & $0,37 \mathrm{bc}$ & $6,8 \mathrm{ab}$ \\
AG7088 PRO & $2,04 \mathrm{ab}$ & $1,41 \mathrm{bc}$ & $2,0 \mathrm{~b}$ \\
2B587 PW & $0,97 \mathrm{ab}$ & $0,29 \mathrm{abc}$ & $2,6 \mathrm{ab}$ \\
DKB390 PRO & $0,84 \mathrm{ab}$ & $0,19 \mathrm{c}$ & $5,8 \mathrm{ab}$ \\
BRS1060 & $0,25 \mathrm{~b}$ & $0,4 \mathrm{abc}$ & $3,4 \mathrm{ab}$ \\
RB9308 YG & $0,94 \mathrm{ab}$ & $0,35 \mathrm{bc}$ & $2,9 \mathrm{ab}$ \\
BALU761 & $2,37 \mathrm{a}$ & $1.08 \mathrm{a}$ & $9,6 \mathrm{ab}$ \\
30F53 YH & $1,29 \mathrm{ab}$ & $0,83 \mathrm{ab}$ & $21,1 \mathrm{a}$ \\
BRS2020 & $1,19 \mathrm{ab}$ & $0,32 \mathrm{bc}$ & $4,9 \mathrm{ab}$ \\
\hline CV\% & 35,02 & 27,26 & 8,67 \\
\hline
\end{tabular}

${ }^{1}$ Values represent the original data, which for the analysis of variance were transformed by: $\mathrm{x}=\operatorname{arcsen} \sqrt{\mathrm{x}} / 100$. Means followed by the same letter do not differ statistically by the Tukey test at $5 \%$

More than 500 types of mycotoxins have already been identified, however the ones with more importance for agriculture, responsible for the highest rates of contamination of grains, seeds and other foods are: the aflatoxins produced by fungi of Aspergillus genre, like A. flavus and A. parasiticus; the ochratoxins produced by the Aspergillus and Penicillium and the fusarium-toxins that carry as important representants the thricothecenes, zearalenones ( $F$. graminearum and $F$. poae), and the fumonisins $(F$. verticillioides and $F$. subglutinans), vomitoxins, ( $F$. verticillioides), T-2 toxin ( $F$. sporotrichioides) produced by many species of the Fusarium genre. In Brazil, the more important mycotoxins, due to their high toxicity and contamination of food are the aflatoxins (MALLMANN \& DILKIN, 2007; PINTO, 2007).

With the opening of new markets for exportation and food production, the preoccupation with food risks and with the development of pathologies, the sanitary quality of the produced primary material, like maize, becomes necessary and demands priority (BENTO et al., 2012).

The fungi that cause damaged grains infect the grains in many different periods, from the plants still on field to the post-harvest, however, many environmental, genetic and management factors interfere 
directly on this process. Thus, there must have attention for the correct use of the practices for integrated production management and control of diseases on field and post-harvest, like the appropriate storage place with the most adequate phytosanitary conditions.

\section{CONCLUSIONS}

The damaged and asymptomatic grains of the cultivars presented a very diverse mycoflora and had as main associated genres the Fusarium, Cladosporium, Penicillium, and Aspergillus. The cultivars presented damaged grains percentage under the standards established by the Brazilian regulations. The asymptomatic grains presented high incidence of the genres Fusarium, Penicillium and Aspergillus.

\section{ACKNOWLEDGEMENTS}

To Capes for the financial support, to the Federal University of Tocantins and to EMBRAPA Maize and Sorghum for the technical and structural aid.

\section{REFERENCES}

BARNETT, H. L.; HUNTER, B. B. 1972. Illustrated genera of imperfect fungi. Minneapolis: Minnesota: Burgess Publishing Company. ed.3, p.241.

BENTO, L. F.; CANEPPELE, M. A. B.; ALBUQUERQUE, M. C. F.; KOBAYASTI, L.; CANEPPELE, C.; ANDRADE, P. J. 2012. Ocorrência de fungos e aflatoxinas em grãos de milho. Revista do Instituto Adolfo Lutz. São Paulo, v.71, n.1, p.44-49.

CASA, R. T.; MOREIRA, E. N.; BOGO, A.; SANGOI, L. 2007. Incidência de podridões do colmo, grãos ardidos e rendimento de grãos em híbridos de milho submetidos ao aumento na densidade de plantas. Summa Phytopathologica. Santa Catarina, v.33, n.4, p.353-357.

FESSEL, S. A.; SADER, R.; PAULA, R. C.; GALLI, J. A. 2003. Avaliação da qualidade física, fisiológica e sanitária de sementes de milho durante o beneficiamento. Revista Brasileira de Sementes. Brasília, v.25, n.2, p.70-76.

FREIRE, F. C. O.; VIEIRA, I. G. P.; GUEDES, M. I. F.; MENDES, F. N. P. 2007. Micotoxinas: importância na alimentação e na saúde humana e animal. Fortaleza: Embrapa Agroindústria Tropical. (Comunicado Técnico, 110). p.1- 48.

FIGUEIRA, E. L. Z.; COELHO, A. R.; ONO, E. Y. S.; HIROOKA, E. Y. 2003. Milho: riscos associados à contaminação por Fusarium verticillioides e fumonisinas. Semina: Ciências Agrárias. Londrina, v.24, n.2, p.359-378.

HENNING, F. A.; JACOB JUNIOR, E. A.; MERTZ, L. M.; PESKE, S. T. 2011. Qualidade sanitária de sementes de milho em diferentes estádios de maturação. Revista Brasileira de Sementes. Brasília, v.33, n2, p.316-321.

HERMANNS, G.; PINTO, F. T.; KITAZAWA, S. E. 2006. Fungos e fumonisinas no período précolheita do milho. Ciência e Tecnologia de Alimentos. Campinas, v.26, p.7-10. 
HUSSAIN, N.; HUSSAIN, A.; ISHTIAQ, M.; AZAM, S.; HUSSAIN, T. 2013. Pathogenicity of two seed-borne fungi commonly involved in maize seeds of eight districts of Azad Jammu and Kashmir, Pakistan. African Journal of Biotechnology. Lagos, v.12, p. 1363-1370.

MALLMANN, C. A.; DILKIN, P. 2007. Micotoxinas e micotoxicoses em suínos. Santa Maria: Editora Palotti, p. 240.

OliveirA, J. A.; CARVAlhO, M. L. M.; VIEIRA. M. G. G. C.; PINHO, É. V. R. V. 1999. Comportamento de sementes de milho colhidas por diferentes métodos, sob condições de armazém convencional. Ciência e Agrotécnica. Lavras, v.23, n.2, p.289-302.

PEZZINI, V.; VALDUGA, E.; CANSINAI, R. L. 2005. Incidência de fungos e micotoxinas em grãos de milho armazenados sob diferentes condições. Revista do Instituto Adolfo Lutz. São Paulo, v.64, p. 91-96.

PINTO, N. F. J. DE A. 2005. Grãos ardidos em milho. Circular técnica EMBRAPA CNPMS, Sete Lagoas, n 66, p.6.

PINTO, N. F. J. A.; VARGAS, E. A.; PREIS, R. A. 2007. Qualidade sanitária e produção de fumonisina B1 em grãos de milho na fase de pré-colheita. Summa Phytopathologica. Botucatu, v.33, n.3, p. 304-306.

RAMOS, A. T. M.; MORAES, M. H. D.; CARVALHO, R. V.; CAMARGO, L. E. A. 2010. Levantamento da micoflora presente em grãos ardidos e sementes de milho. Summa Phytopathologica. Botucatu, v.36, n.3, p.257-259.

SILVA, F. A. S. 2015. ASSISTAT - Assistência Estatística - versão 7.7 beta (pt). Programa computacional. Departamento de Engenharia Agrícola, Universidade Federal de Campina Grande, Paraíba, Brasil.

SILVA, F. C.; CHALFOUN, S. M.; BATISTA, L. R.; SANTOS, C.; LIMA, N. 2015. Taxonomia polifásica para identificação de Aspergillus seção flavi: uma revisão. Revista Ifes Ciência, Espirito Santo, v.1, p. 18-40.

WORDELL FILHO, J. A.; SPAGNOLLO, E. 2013. Sistema de cultivo e doses de nitrogênio na sanidade e no rendimento do milho. Ciência Rural. Santa Maria, v. 43, n. 2, p. 199-205. 